\title{
ANENCEPHALUS AND WATER HARDNESS IN SOUTH-WEST LANCASHIRE
}

\author{
D. W. FIELDING \\ Department of Child Health, University of Liverpool, \\ AND \\ R. W. SMITHELLS \\ Department of Paediatrics and Child Health, University of Leeds
}

The well-known regional variation in the incidence of anencephalus in England and Wales, whereby the defect occurs more frequently in Wales and in northern England than in East Anglia and southeast England, has suggested a possible relationship to water hardness (Penrose, 1957; Stocks, 1970; Fedrick, 1970). When the whole area of England and Wales is examined, a strong negative correlation is found between these two variables.

In order to establish whether the connexion is causal, further information is needed. First, correlations between water hardness and anencephalus need to be sought within much more circumscribed areas, as has been done in South Wales by Lowe, Roberts, and Lloyd (1971). Second, correlations need to be sought between annual variations in water hardness and anencephaly within one area, especially where water hardness has been deliberately altered by the introduction of water-softening plant. If soft water does indeed contribute towards a higher incidence of anencephalus, it remains a matter of conjecture as to when and how this effect is brought about. Serial observations over a period shorter than a generation can only shed light on the possibility of short-term effects, i.e., the possibility that the hardness of the water consumed by a parent at the time of relevant gametogenesis, or by a pregnant woman in early pregnancy, may affect neural-tube closure in the embryo. The possibility of an effect operative during the mother's prenatal life or early childhood could be investigated only over a much longer period.

Congenital malformations have been ascertained systematically in the population of Liverpool since 1960 (Smithells, 1962). From July 1963 until June 1968 , the area of ascertainment was extended to include neighbouring parts of south-west Lancashire. This is a predominantly soft-water area but includes Southport, where the water is hard, and St. Helens, where it was hard at the beginning of the study period but was softened after three years (Table I).
All data on anencephalic births have been checked by reference to maternity department records. These sources were also used to provide information

TABLE I

ANALYSES OF WATER

\begin{tabular}{l|c|c|c|c}
\hline & $\begin{array}{c}\text { Liverpool } \\
\text { (average } \\
1963-70)\end{array}$ & $\begin{array}{c}\text { Southport } \\
\text { (average } \\
1963-70)\end{array}$ & $\begin{array}{c}\text { St. Helens } \\
\text { (average } \\
1963-65)\end{array}$ & $\begin{array}{c}\text { St. Helens } \\
\text { (average } \\
1966-70)\end{array}$ \\
\hline $\begin{array}{c}\text { Total hardness } \\
\text { (p.p.m.) }\end{array}$ & 59 & 268 & 251 & 123 \\
pH & $7 \cdot 1$ & $7 \cdot 4$ & $7 \cdot 0$ & $7 \cdot 1$ \\
\hline
\end{tabular}

on anencephalic births in Southport and St. Helens for the period July 1968 to December 1970. The number of cases of anencephalus, total births, and incidence of anencephalus for each year of the period 1963-70 in Liverpool, Southport, and St. Helens is shown in Table II. During the seven-and-a-half-year period under review the incidence of anencephalus in Liverpool was 2.9, in Southport 3.9, and in St. Helens 3.3 per 1,000 total births. The incidence in the two hard-water areas combined was 3.5 per 1,000 , a figure higher than that for soft-water Liverpool. These areas are not identical in social class or maternal age/parity distribution, but the differences are such as to lead one to expect a higher incidence of anencephalus in Liverpool. Furthermore, if the standard of ascertainment was significantly different it would favour a higher recorded rate in Liverpool. The high rate in Southport is particularly striking and is contrary to expectation. It is higher than in St. Helens, and water hardness is greater than in St. Helens (Table I). These data are not in accord with the negative correlation between water hardness and the incidence of anencephalus in England and Wales as a whole.

A more satisfactory test of the relationship could be made by observing a single area over a period of time in which water hardness changed. In Liverpool 
TABLB II

INCIDENCE OF ANENCEPHALUS

\begin{tabular}{|c|c|c|c|c|c|c|c|c|c|c|}
\hline & \multicolumn{3}{|c|}{ Liverpool } & \multicolumn{3}{|c|}{ Southport } & \multicolumn{3}{|c|}{ St. Helens } & $\overline{\vec{\omega}}$ \\
\hline & \multirow{2}{*}{$\begin{array}{l}\text { Total } \\
\text { Births }\end{array}$} & \multicolumn{2}{|c|}{ Anencephalus } & \multirow{2}{*}{$\begin{array}{l}\text { Total } \\
\text { Births }\end{array}$} & \multicolumn{2}{|c|}{ Anencephalus } & \multirow{2}{*}{$\begin{array}{l}\text { Total } \\
\text { Births }\end{array}$} & \multicolumn{2}{|c|}{ Anencephalus } & C \\
\hline & & Births & $\begin{array}{c}\text { Rate per } \\
1000\end{array}$ & & Births & $\begin{array}{l}\text { Rate per } \\
1000\end{array}$ & & Births & $\begin{array}{c}\text { Rate per } \\
1000\end{array}$ & $\frac{\bar{\sigma}}{\overline{\bar{\sigma}}}$ \\
\hline $\begin{array}{l}1963 \text { (half-year) } \\
1964 \\
1965 \\
1966 \\
1967 \\
1968 \\
1969 \\
1970\end{array}$ & $\begin{array}{r}9,000 \\
18,194 \\
16,520 \\
15,401 \\
12,806 \\
13,544 \\
12,851 \\
12,267\end{array}$ & $\begin{array}{l}30 \\
54 \\
43 \\
40 \\
50 \\
29 \\
34 \\
38\end{array}$ & $\begin{array}{l}3 \cdot 3 \\
3 \cdot 0 \\
2 \cdot 6 \\
2 \cdot 6 \\
3 \cdot 9 \\
2 \cdot 1 \\
2 \cdot 6 \\
3 \cdot 1\end{array}$ & $\begin{array}{r}554 \\
1,155 \\
1,103 \\
1,144 \\
1,154 \\
1,154 \\
985 \\
995\end{array}$ & $\begin{array}{l}3 \\
5 \\
6 \\
5 \\
3 \\
2 \\
3 \\
5\end{array}$ & $\begin{array}{l}5 \cdot 4 \\
4 \cdot 3 \\
5 \cdot 4 \\
4 \cdot 4 \\
2 \cdot 6 \\
1 \cdot 7 \\
3 \cdot 0 \\
5 \cdot 0\end{array}$ & $\begin{array}{r}970 \\
1,872 \\
1,877 \\
1,814 \\
1,780 \\
1,976 \\
1,858 \\
1,935\end{array}$ & $\begin{array}{r}2 \\
6 \\
8 \\
8 \\
6 \\
1 \\
5 \\
10\end{array}$ & $\begin{array}{l}2 \cdot 1 \\
3 \cdot 2 \\
4 \cdot 3 \\
4 \cdot 4 \\
3 \cdot 4 \\
0 \cdot 5 \\
2 \cdot 7 \\
5 \cdot 2\end{array}$ & $\begin{array}{l}\vec{D} \\
\stackrel{2}{0} \\
\text { ल } \\
\overrightarrow{0} \\
\overrightarrow{0} \\
\vec{\omega}\end{array}$ \\
\hline \multirow[t]{3}{*}{ Total } & 110,583 & 318 & 2.9 & 8,244 & 32 & 3.9 & 14,082 & 46 & $3 \cdot 3$ & \\
\hline & & & & & & $1963-65$ & 4,719 & 16 & 3.4 & \\
\hline & & & & & & $1966-70$ & 9,363 & 30 & $3 \cdot 2$ & \\
\hline
\end{tabular}

between 1960 and 1970 water hardness was always at a low level, fluctuating between 42 and 77 p.p.m. Figure 1 shows fluctuations in the incidence of anencephalus which bear no constant relationship to minor fluctuations in water hardness. During this decade water-softening plant was introduced at St. Helens. The water supply to St. Helens is complex, being derived from five main sources. Two of these sources, which together supply more than $80 \%$ of St. Helens water, were softened from 1966. Figures for water hardness in St. Helens in Table I are for a theoretical pooled sample, the hardness for each of the five sources being represented in proportion to their contribution to the total water supply (see Table III). Figure 2 shows no apparent effect of water softening on the incidence of anencephalus, although the number of anencephalic births each year is small and fluctuations in incidence are therefore exag- $-\frac{-}{V}$ gerated. The incidence of anencephalus in the threeo years before softening (1963-65) was 3.4 per 1,000 births (16 cases) and in the five years after softening $Z$ (1966-70) $3 \cdot 2$ per 1,000 (30 cases).

\section{Discussion}

The negative correlation reported by others between the regional incidence of anencephalus a $\overrightarrow{\mathrm{A}} \mathrm{d} \overrightarrow{\mathrm{e}}$ water hardness is, in a sense, a circular argumenit..The hypothesis that water hardness may be causalty related to the defect arises from observing its geo-s graphical distribution. Since geography, geology, and water hardness are closely interrelated the cor-0 relation is to be expected when examined over the $\triangle$ whole of England and Wales. The hypothesis has $=$ now been tested in a smaller area and no such corre- $\frac{0}{3}$

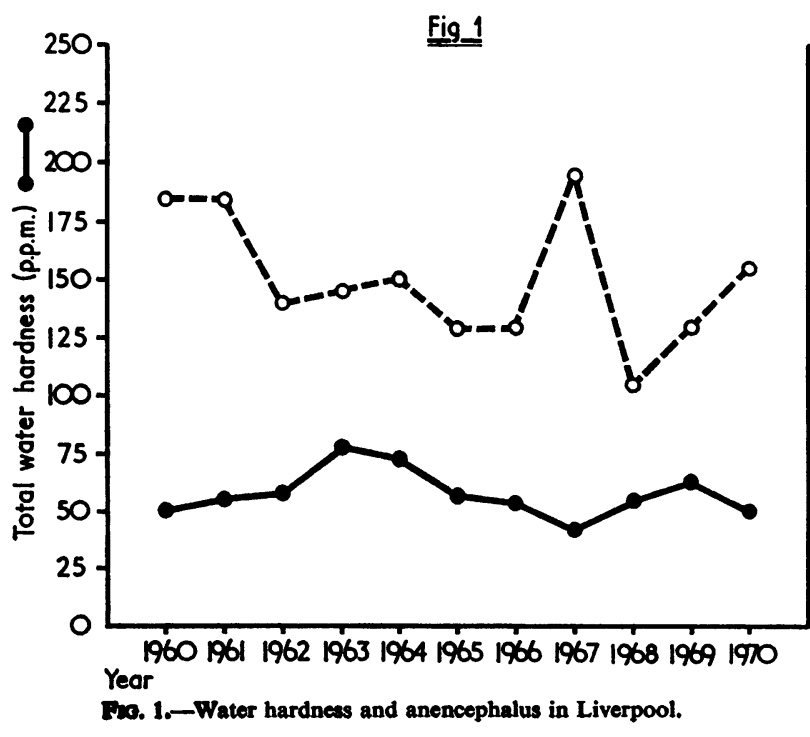

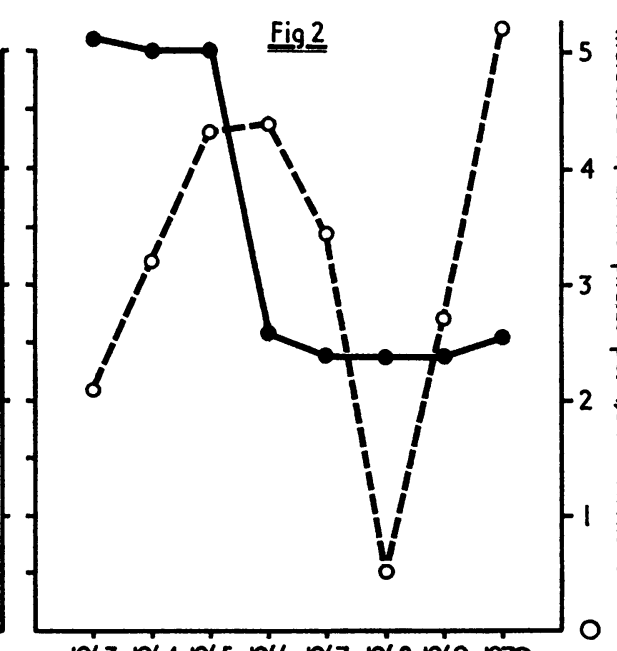

19631964196519661967196819691970

FIG. 2.-Water hardness and anencephalus in St. Helens. 
TABLE III

WATER HARDNESS IN ST. HELENS

\begin{tabular}{|c|c|c|c|c|c|c|c|c|c|c|c|c|c|c|c|c|c|}
\hline \multirow[b]{2}{*}{ Water } & \multirow{2}{*}{$\begin{array}{c}\% \text { of Total } \\
\text { Water Supply } \\
\text { (a) }\end{array}$} & \multicolumn{2}{|c|}{1963} & \multicolumn{2}{|c|}{1964} & \multicolumn{2}{|c|}{1965} & \multicolumn{2}{|c|}{1966} & \multicolumn{2}{|c|}{1967} & \multicolumn{2}{|c|}{1968} & \multicolumn{2}{|c|}{1969} & \multicolumn{2}{|c|}{1970} \\
\hline & & $\underset{(b)}{T H}$ & $(a \times b)$ & $\underset{(b)}{\text { TH }}$ & $(a \times b)$ & $\underset{(\text { b) }}{\text { TH }}$ & $(a \times b)$ & $\underset{(b)}{T H}$ & $(a \times b)$ & $\underset{(b)}{T H}$ & $(a \times b)$ & $\underset{(b)}{T H}$ & $(a \times b)$ & $\underset{(b)}{T H}$ & $(a \times b)$ & $\underset{(b)}{\text { TH }}$ & $(a \times b)$ \\
\hline $\begin{array}{l}\text { Brown Edge } \\
\text { Knowsley } \\
\text { Eccleston } \\
\text { Sutton } \\
\text { Whiston }\end{array}$ & $\begin{array}{l}60 \\
21 \cdot 25 \\
8 \cdot 75 \\
6 \cdot 25 \\
3 \cdot 75\end{array}$ & $\begin{array}{l}293 \\
223 \\
197 \\
121 \\
183\end{array}$ & $\begin{array}{r}176 \\
47 \\
17 \\
7 \\
7\end{array}$ & $\begin{array}{l}266 \\
218 \\
296 \\
174 \\
194\end{array}$ & $\begin{array}{r}160 \\
46 \\
26 \\
11 \\
7\end{array}$ & $\begin{array}{l}270 \\
224 \\
262 \\
148 \\
192\end{array}$ & $\begin{array}{r}162 \\
48 \\
23 \\
9 \\
7\end{array}$ & $\begin{array}{l}91 \\
190 \\
228 \\
130 \\
192\end{array}$ & $\begin{array}{r}55 \\
40 \\
20 \\
8 \\
7\end{array}$ & $\begin{array}{l}102 \\
108 \\
226 \\
142 \\
190\end{array}$ & $\begin{array}{r}61 \\
23 \\
20 \\
9 \\
7\end{array}$ & $\begin{array}{r}85 \\
146 \\
247 \\
131 \\
192\end{array}$ & $\begin{array}{r}51 \\
31 \\
22 \\
8 \\
7\end{array}$ & $\begin{array}{r}96 \\
114 \\
254 \\
121 \\
198\end{array}$ & $\begin{array}{r}58 \\
24 \\
22 \\
8 \\
7\end{array}$ & $\begin{array}{l}104 \\
132 \\
256 \\
149 \\
192\end{array}$ & $\begin{array}{r}62 \\
28 \\
22 \\
9 \\
7\end{array}$ \\
\hline Pooled average & & & 254 & & 250 & & 249 & & 130 & & 120 & & 119 & & 119 & & 128 \\
\hline
\end{tabular}

TH=total hardness.

lation is found. However, we recognize that variations in incidence or even epidemics might not be contemporaneous with relevant environmental changes. Migrant studies (Naggan and MacMahon, 1967; Hobbs, 1969; Leck, 1969) show that racial differences in the incidence of anencephalus are little affected by population movements. At present the balance of evidence makes it unlikely that the nature of the local water supply plays any short-term part in the pathogenesis of anencephalus.

\section{SUMMARY}

The incidence of anencephalus in England and Wales is higher in the north and west where the water is softer. A possible causal relationship has been suggested by others. In south-west Lancashire the incidence of anencephalus in Liverpool (soft water) is lower than in Southport and St. Helens (hard water). Serial observations in Liverpool from 1960 to 1970 show no relationship between water hardness and the incidence of anencephalus, and the introduction of water-softening plant in St. Helens does not appear to have influenced the incidence of anencephalus in this town so far.

We wish to thank Mr. J. F. Clark and Mr. W. P. Robinson, Liverpool city analysts; Mr. N. Macmillan, supply engineer, West Lancashire Water[Board; Mr. R. F. Millar, water engineer, St. Helens Corporation; Miss
Robinson, superintendent midwife, St. Helens; and Mrs. E. F. McAllister, research assistant.

This work was carried out in the Institute of Child Health, Alder Hey Children's Hospital, Liverpool, and was supported financially by the United Liverpool Hospitals Research Fund.

\section{REFERENCES}

FEDRICK, J. (1970). Anencephalus and the local water supply. Nature (Lond.), 227, 176.

HoBss, M. S. T. (1969). Risk of anencephaly in migrant and non-migrant women in the Oxford area. Brit. J. prev. soc. Med., 23, 174.

LECK, I. (1969). Ethnic differences in the incidence of malformations following migration. Brit. J. prev. soc. Med., 23, 166.

Lowe, C. R., RoberTs, C. J., and LLOYD, S. (1971). Malformations of central nervous system and softness of local water supplies. Brit. med. J., 2, 357.

NAGGaN, L., and MacMahoN, B. (1967). Ethnic differences in the prevalence of anencephaly and spina bifida in Boston, Massachusetts. New Engl. J. Med., 277, 1119.

Penrose, L. S. (1957). Genetics of anencephaly. J. ment. Defic. Res., $1,4$.

SMrthells, R. W. (1962). The Liverpool congenital abnormalities registry. Develop. Med.Child. Neurol., 4,320.

STocks, P. (1970). Incidence of congenital malformations in the regions of England and Wales. Brit. J. prev. soc. Med., 24, 67. 